\title{
Information and Communication Technologies and Sustainable Livelihood Opportunities: A Study of Information Behavior Among Malaysian Youth
}

\author{
Zeinab Zaremohzzabieh ${ }^{1}$, Ismi Arif Ismail ${ }^{1}$, Normala Ismail ${ }^{1}$, Siti Zobidah Omar $^{2}$, Jusang Bolong ${ }^{2}$ \\ ${ }^{1}$ Faculty of Educational Studies, Universiti Putra Malaysia, 43400 UPM Serdang, Selangor, Malaysia \\ ${ }^{2}$ Faculty of Modern Languages and Communication, Universiti Putra Malaysia, 43400 UPM Serdang, Selangor, \\ Malaysia \\ Correspondence: Ismi Arif Ismail, Faculty of Educational Studies, Universiti Putra Malaysia, 43400 UPM \\ Serdang, Selangor, Malaysia. Tel: 603-8946-8232. E-mail: ismi@upm.edu.my
}

Received: September 3, $2021 \quad$ Accepted: September 28, $2021 \quad$ Online Published: October 14, 2021

doi:10.5539/ass.v17n11p57 URL: https://doi.org/10.5539/ass.v17n11p57

\begin{abstract}
Information and communication technology (ICT) is a significant instrument for youth empowerment, since it allows instant interaction, thus enabling information needs and community development. This study aims to explore the cumulative knowledge on how youths use ICT as an essential part of their daily lives. A quantitative study was carried out and the data were analyzed by the structural equation modeling technique (SEM). The results confirmed that information needs and sharing have a positive influence on the sustainable livelihood of Malaysian youth. However, the findings also reveal that there was no significant relation between two of these predictors (i.e. information seeking and information source) and the sustainable livelihoods of Malaysian youth. Due to its unique perspective, this study contributes to the existing literature on youth information behavior in ICT environments.
\end{abstract}

Keywords: ICT, Sustainable livelihood, Youth, Information behavior, Malaysia

\section{Introduction}

Information and communication technology (ICT) is an efficient tool to increase livelihood opportunities. The youth of today have stated that having access to ICT is an important priority in their lives (Brown et al., 2016). This is not surprising; as digital natives in this technological age, youths are assumed to have interest in hi-tech gadgets and the latest technologies. ICT is employed not just as an uncomplicated tool for communication, but also as a method to help them decrease global deficiencies and inequalities in socio-economic circumstances and situations (Sobeih, 2007). It should be noted that ICT can enable youth to access information and knowledge on a range of topics that could directly affect them, such as healthcare, education, and employment. The information enables them to gain employment and advance towards more sustainable livelihoods. Additionally, ICT is used as a solution to gather relevant information for youth marginalization to alleviate poverty, which leads to an investigation into what and how much information is needed.

The nexus of information, such as use, need, searching, storage, and sharing combined with ICT usage, is referred to as information behavior (Fisher \& Julien, 2009). According to Williamson and Roberts (2010), information behavior is embedded in social communication with a large amount of information transfer arising from relational communication. Subsequently, the collection and sharing of information are performed in groups, by individuals who provide knowledge with individuals who are reliant on this knowledge. Saunders et al. (2017) stated that this has provoked the term human information behavior, which refers to the behavior of people who nourish their information needs by seeking and sharing information.

Indeed, information behavior shows that the growth of ICT has influenced information access through the use of ICT by youth, since they consider ICT to have all the information they require. In an online context, youth information behavior research aims to capture a variety of young engagements in information activities for a variety of livelihood purposes. The advancement of ICT has offered a view that youth have come up against a situation where they are faced with information and therefore have evolved into a more knowledgeable society. Currently, knowledge is power. To generate a knowledgeable and well-informed society, there should be enough 
foundations or channels to access that knowledge. The community is continuously viewed as having updated knowledge and information, enabling them to easily access information. Nowadays, the younger generation spends a considerable amount of time on ICT usage (Silva et al., 2018); hence, it has been a key interest to investigate youth's information behavior by using it. In recent years, a number of studies have looked into the youth's long-term sustainable livelihood in Malaysia (e.g., Soh \& Omar, 2017). There have, however, been no studies explicitly looking at the information behaviour of Malaysian adolescents. The current study intends to bridge this gap by examining the relationship between information seeking, sources, need, and sharing, as well as sustainable living. The present study addresses the call for more research to evaluate whether sustainable livelihoods are associated with Malaysian youth information behavior and the extent to which ICT influences such behavior.

\section{The Current Study}

In Malaysia, 43\% of the total population falls under the youth classification (Ming et al., 2012). This population has valuable capabilities and is uniquely beneficial for the growth of the country. They are supposed to drive economic and community developments, especially in low-income households and communities in need of economic development. Despite these high expectations for the Malaysian youth, there are many concerns about their healthcare, well-being, and future direction. Recent local studies have indicated several areas of concern including engagement in at-risk behaviors, healthcare, character development, employability and vocational readiness, development, social isolation, empowerment, and leadership development (Lee, 2012; MYI, 2011). According to Dahalan et al. (2013), the big question on development is whether Malaysian youth have the sustainable livelihood opportunities to function as successful globally competitive adults who not only can survive but also succeed in leading a fully developed Malaysia. Certainly, information is essential for the youth to respond to the sustainable livelihood assets and challenges in their community. They need information for effective decision-making to improve their livelihood activities as well as develop both their community and themselves. Without information, they would remain in the same state without growth or development.

Malaysian youth have identified ICT as a catalyst for change. This includes changes in lifestyle, information handling, and exchange of information, learning approaches as well as developing social and economic conditions (Ahmad et al., 2012). ICT usage can assist youths to access knowledge and information on selected subjects that significantly affect them, such as education, well-being, healthcare, and services. Additionally, ICT may benefit them and lead to sustainable livelihoods through the acquisition of required information and knowledge. Their building capacity depends largely on the amount of information they can capture via technologies. As youth accumulate increasing amounts of information, they can respond to external stimuli more quickly and effectively, therefore transforming to improve their sustainable livelihood and communities. Accordingly, they require, search for, and use information in all aspects of their livelihood activities. At this point, their information activities, along with their ICT usage, must change to a new reformed structure by passing through information needs, searching, and related behaviors; thus, the developing role of information is directed to a new rationale for the purpose and meaning of ICT in the Malaysian society.

In recent times, studies that highlight the effects of ICT on sustainable livelihood in communities have grown in number (Blake \& Garzon, 2012; Kivunike et al., 2013; Makoza \& Chigona, 2012; Sæbø \& Thapa, 2012). Some studies also revealed that information access attained through ICT usage offers social and economic empowerment to all, including deprived populations, improved their skills, and connected many institutions that were involved in sustainable livelihoods (Mbuyisa \& Leonard, 2017). Adera, Waema, and May (2014) argued the value of ICT as a component to eradicate poverty when the possible information was recognized as an intentionally growing source that must be merged as a regular component of the development planning practice. Many researchers have also applied the sustainable livelihood (SL) framework, which only provided an image of the needs and problems of such communities, and focused on what marginalized people lack. In the context of information technology, the SL framework also ignored initiating factors of information knowledge and communication. Besides, the persistent view has been that ICT did not directly influence the SL framework (Gigler, 2014). It is then appropriate for us to explore the unique ways in which ICT is employed to address the main catalysts for information and knowledge that depicted the ICT roles in the lives of Malaysian youth. Thus, this study aims to fill the knowledge gap in this area of research by gaining a deeper understanding into the information behavior factors that potentially influence the sustainable livelihood of Malaysian youth.

\section{Literature Review and Hypothesis Development}

Based on previous studies, this study provides an account of how ICT was employed by youths to enhance information as an imperative part of their daily lives. Additionally, the study emphasizes the positions of four 
predictor sub-groups, namely, information source, information seeking, information need, and information sharing.

\subsection{Information Source}

Young people use information frequently as part of their daily lives. Information linked to work, leisure, household, wellbeing, income and a host of other subjects, is sought from a wide range of information sources. In this study, an information source refers to something that stores information. Recently, a number of these sources are becoming increasingly digitalized and youths now are especially exposed to the rich graphic information provided by digital media. A growing number of studies indicate that youths team up to solve problems using Wikipedia and different reality games as well as share and circulate information by YouTube, social networking sites (SNSs), podcasting, and photo sharing sites (Kirschner \& De Bruyckere, 2017). In addition, Sarka and Ipsen (2017) described that Generation Y grew up alongside the World Wide Web (WWW) and that the Web was raised with Generation Y. Other studies showed that Generation Y students grew up around the Internet and the Web at a very young age (Kim, 2018). In Malaysia, there has been a massive fall in the proportion of youth who do not use Internet access for seeking information in the past five years, from 67 percent in 2007 to 2 percent in 2012; this implies how fast Malaysian youths have evolved to utilize the World Wide Web as an information source (Ming et al., 2012). Also, the results of the previous study provide us with evidence that Malaysian young adults aged 20 to 24, also known as Generation Y use the Internet and social media technologies for teaching and learning processes as well as sharing information. Additionally, they are aware of and interested in social and political issues around them (Yusop \& Sumari, 2013).

The Malaysian Youth Index (2011) indicates that the Media Penetration score of 87.4 for 2011 was a little higher than the 2006 score of 84.8 and 2008 score of 85.0. Malaysian youth continue to be vastly involved with media and ICTs of dissimilar types. For instance, scores for the traditional forms of media such as TV, radio, newspaper, and computer remained high but quite unchanged as compared to 2006 and 2008, showing that the younger generation still depends on them as vital sources of information. However, Internet use revealed significantly higher scores than the previous Index, showing the stable growth of youth exposure to global media and ICT.

Thus, the study of the relationship between development and ICTs has currently been redeployed to evaluate if there is a causal connection between information sources and youths' sustainable livelihood. It has been recognized that maximizing the advantages of the use of information sources may ease the achievement of development causes (Brown \& Grant, 2010).

\subsection{Information Seeking}

The present study discusses the information-seeking process as a part of the larger information behaviors of youths with regards to their livelihood opportunities and does not attempt to consider it separately. Information seeking is one of the most common online activities for young people and can lead to extra information networks, which may develop their sustainable livelihood. Information and knowledge-seeking among youth have varied significantly as they wish to pursue virtual information (Omar et al., 2012). Youths use ICTs to search for information about livelihood opportunities available to them. According to Jayasundara (2021), it is the main activity of life and people seek information to broaden their understanding of the world around them. In addition, many academic disciplines are concerned with understanding how people search, the ways used to get access to all information, and reasons that restrain or inspire information-searching behavior. Johnson and Case (2012) illustrated information-seeking as a mindful attempt to obtain information as a reply to a need for information. Kassim and Katunzi-Mollel (2017) also explained information-seeking as a way of recognizing, selecting, and placing the possible information sources that could fulfill the information needs of a person. Adeola (2014) stated that it is a technique that ICT users can use as both senders and receivers. In this study, the greatest important feature when seeking information, sources of sustainable livelihood information concerning their usefulness and relevance to the youth work are required for information seeking.

\subsection{Information Need}

Facts of the information behavior suggested that ICT development has influenced access to information in the manner that young people use ICT since they consider ICT to have all the info they need. The need for info is one of the reasoning needs of humankind. According to Agarwal (2017), information need is frequently recognized to originate from an unclear realization of something required and as settling in placing the info that is a factor to recognition and comprehension. Thus, it takes into account that there is a condition to know the users' needs for the aim that the origin of any information behavior is understood to be the idea of information need. It is divided into many groups including the need to explain the information gained, the need for new information, and the need to verify known information (Cerdan et al., 2017). 
For marginalized populations like youths in growing nations, information needs can affect not only their way of life but also their existence. As a result, it's critical to look at the intricate relationship between information needs and the survival of local communities. Young Malaysians who have access to the proper information can develop the skills, knowledge, and confidence they need to actively engage in community affairs. Furthermore, as ICTs become more widely available in Malaysia, further research is needed to examine how these newer information resources are enhancing the unique information requirements of young Malaysians. As a result, a better knowledge of youth's ability to use ICTs at various levels is critical for identifying appropriate methods and organizations for the transmission of important information.

\subsection{Information Sharing}

The livelihood information system must be able to communicate information horizontally across communities at the same level as well as vertically between communities at other levels. Vertical systems perform well among a few highly incorporated communities with compatible information systems (Duncombe, 2014). Horizontal systems succeed in settings where numerous diverse communities form a frequently changing network of followers who desire to share actual certain information (Duncombe, 2014). In today's highly networked settings, a new actual model for information sharing is required, with more sharing processes operating in a loose but compatible global information network. It enables the sharing of big quantities of quality data between youths and their communities. Youths need capacity building, not just in using ICTs but in sharing information in a way that assists their livelihoods. The opportunity to reorganize information networking and grow local solutions to the development of problems stems from the possibility of improved collaborations. Community knowledge partnerships can grow around collective objects, and information can be swapped between youths and communities that share these. Partnerships based on information sharing can assist to exceed more formal institutional obstacles to replace. Partnerships can assist to improve a large range of new political, economic, and social networks that can signify different opportunities to youths according to their livelihoods. Information sharing thus signifies a method that provides opportunities to youth and communities. Partnerships can be improved to control these opportunities for short-term and shared benefits or longer developmental term and societal change. Partnerships can also improve methods to deal with the problems of connectivity and incorporate external and local knowledge; can directly benefit marginalized communities, especially youths (Zhan et al., 2016). This method could change the conventional method of a 'one-way' flow of information from a systematic, rich core of information to remote marginalized information communities, with active information-sharing partnerships consisting of a two-way flow of information at every level. The current study sought to examine the following hypotheses.

Hypothesis One: There is a relationship between information sources and sustainable livelihood.

Hypothesis Two: There is a relationship between information seeking and sustainable livelihood.

Hypothesis Three: There is a relationship between information need and sustainable livelihood.

Hypothesis Four: There is a relationship between information sharing and sustainable livelihood.

\section{Research Methodology}

\subsection{Participants and Procedure}

In this study, the cross-sectional survey design was used for data collection. A multi-stage random sampling technique was utilized for this research and data was acquired from the four districts of Cameron Highlands, Kuala Perlis, Batu Pahat, and Petaling Jaya located in Peninsular Malaysia. The present criteria for the participants were that (a) they should be ICT users and (b) participants' age must be between 18 and 24 years. According to the Malaysian Youth Council, people aged between 15 to 40 years old can be counted as youths whilst the United Nation and Commonwealth Secretariat have their own criteria as they classify those aged between 18 to 24 years old as youths (Azimi \& Zanariah, 2007). A total of 400 questionnaires were distributed among Malaysians of which all 400 valid questionnaires were returned. For the structural equation modelling (SEM) studies, Kline (2016) recommended that 200 or extra participants would be suitable and Ho (2006) recurred that in SEM the sample size must be adequately large. For this study, 400 samples were sufficient to meet the conditions of SEM. All participants were knowledgeable about the aim of the research. Furthermore, they were notified that their responses in this study were completely voluntary and anonymous and that they could withdraw from the survey at any time.

The study employed a quantitative research study via self-administered questionnaires. The data was analyzed using SPSS software, version 21, and Amos software, version 22. Means and standard deviations were then applied to illustrate the five constructs. Besides, the SEM method, i.e., individual constructs, the measurement 
model, and the structural model was used to evaluate the direct associations among constructs.

\subsection{Research Instruments}

In this study, the constructs were assessed on a 5- point Likert scale (strongly disagree to strongly agree). Measurement items relating to each construct were developed based on a review of items in previous studies with proven reliability and validity. Mostly, the reliability of items was proved preliminarily with 40 respondents. Information sources were assessed by a seven-item scale, with Cronbach's alpha value of 0.805 (Hassan, 2011; Ito et al., 2009). Information seeking was measured using a six-item scale, with Cronbach's alpha value of 0.850 (Murgatroyd, 2011). Information need was assessed by seven items adapted from Bashir et al. (2011). The Cronbach's alpha value was 0.768 . Information sharing was assessed by a nine-item scale-revised from Chiu, Hsu, and Wang (2011) and Park et al. (2010) and previous literature review. The value of coefficient alpha was 0.80 . Lastly, sustainable livelihood was measured with five sub-constructs. The sub-constructs for sustainable livelihood are human, social, financial, physical, and natural assets. Sustainable livelihood items were adapted from Yassin et al. (2014), and Petrosillo et al. (2013), with Cronbach's alpha value of 0.837 .

\subsection{Ethical Statement}

The study was authorized by the ethical committee of Universiti Putra Malaysia (Serdang, Malaysia). The participants were told about the study's goals, as well as the fact that participation was completely voluntary and anonymous, and that they may opt out at any moment. All of the subjects gave their written informed permission.

\section{Analysis and Results}

A total of 400 Malaysian youths from the four districts participated in this study (male $=61 \%, \mathrm{n}=244$, and female $=39 \%, \mathrm{n}=156)$, aged from 18 to 24 years (mean $=20.76, \mathrm{SD}=2.25)$. With regards to race, the participants were Malay $(79.7 \%, \mathrm{n}=319)$, Chinese $(10.5 \%, \mathrm{n}=42)$, Indian $(4.5 \%, \mathrm{n}=18)$, and others $(5.3 \%, \mathrm{n}=$ 21). In addition, in terms of educational achievements and background, 35\% ( $\mathrm{n}=140)$ and $3.8 \%(\mathrm{n}=15)$ had obtained education at high school (SPM/STPM) and secondary levels (PMR/SRP/LCE), respectively, while about $1.3 \%(\mathrm{n}=5)$ of the respondents did not have any formal education. $1.3 \%(\mathrm{n}=5)$ of them only completed primary education and $18.8 \%(n=75)$ had a skill certificate. $21.5 \%(n=86)$ of the respondents had diplomas and $18.3 \%(\mathrm{n}=74)$ were degree holders.

In addition, data analysis on job status revealed that $8.8 \%(n=35)$ of the respondents were working as contract workers and $5 \%(\mathrm{n}=20)$ were self-employed, and $40.7 \%(\mathrm{n}=163)$ had permanent jobs. This result also indicates that most of the respondents were unemployed and made up $45.5 \%(n=182)$ of the total population. After the respondents were requested to provide their demographic information at the beginning of the survey, they were asked about their access to the Internet at home and to identify the type of Internet connection provider. The result displayed that almost all respondents who took part in the study indicated that they had access to the Internet. 65\% $(\mathrm{n}=260)$ of them said they had a wireless connection, while $16.8 \%(\mathrm{n}=67)$ used ADSL connection, $7 \%(\mathrm{n}=28)$ used cable to access the Internet at home and 2.2\% $(\mathrm{n}=9)$ used fiber optics to have Internet access. Only $6.5 \%(\mathrm{n}=26)$ and $2.5 \%(\mathrm{n}=10)$ reported being connected at the public center and using satellite, respectively. Notably, wireless was the most widely used connection among these youths with ADSL connection also being significant.

In developing the validity of the overall measurement model, the study recognized five latent constructs, and the measured items were assigned to these latent constructs. However, the sustainable livelihood construct was examined by a CFA parceling (sums or averages of items) approach because the construct had multi-item scales. A CFA parceling method was implemented to decrease the number of items as fit statistics is influenced by the number of items (Shi et al., 2019). Furthermore, Yang, Nay, and Hoyle (2010) stated that the parceling method has been understood to be necessary when there are more than 12 items in a construct and the indicators reflect a one-dimensional construct. Thus, this study considered the sustainable livelihood constructs as a five-factor scale, with subscales measuring human, social, financial, natural, and physical (Zaremohzzabieh et al., 2014). The construct reliability was measured by studying the item and composite reliabilities. Instead of composite reliabilities, this study stated Cronbach's alpha values as implied in Table 2. In this study, the convergent validity along with the discriminant validity was considered to assess the measurement validity. The convergent validity was proven by assessing the average variance extracted (AVE), which implied the total of variance clarified by a latent construct. Table 1 illustrates that the convergent validity for all constructs met the minimum criterion of 0.50 , signifying that all the separate constructs clarified the amount of the variance. In this study, the results revealed that the five constructs displayed adequate discriminant validity and a possible difference among the variables and constructs; meanwhile, Table 1 shows that the AVE for five constructs was greater than the squared coefficients $\left(\mathrm{r}^{2}\right)$ for each pair. 
Table 1. Construct inter-correlation, mean, and standard deviation.

\begin{tabular}{cccccccc}
\hline & 1 & 2 & 3 & 4 & 5 & Mean & $S D$ \\
\hline 1. Information Sources & 0.50 & & & & & 3.54 & 1.069 \\
2. Information Need & 0.292 & 0.519 & & & & 3.45 & 0.639 \\
3. Information Seeking & 0.290 & 0.251 & 0.507 & & & 3.82 & 0.737 \\
4. Information Sharing & 0.287 & 0.162 & 0.242 & 0.574 & & 3.22 & 0.797 \\
5. Sustainable Livelihood & 0.282 & 0.178 & 0.228 & 0.552 & 0.544 & 3.435 & 0.563 \\
\hline
\end{tabular}

Note. The square roots of the average variance extracted (AVE) are the diagonal elements (in bold). Correlations between constructs are off-diagonal elements. The diagonal elements should be bigger than the off-diagonal elements for discriminant validity

Table 2. Measurement model resulting from CFA.

\begin{tabular}{|c|c|c|c|c|}
\hline Constructs and indicators (items/parcels) & $\begin{array}{c}\text { Standardized } \\
\text { Factor } \\
\text { Loading }\end{array}$ & AVE & $\begin{array}{l}\text { Composite } \\
\text { Construct } \\
\text { Reliability }\end{array}$ & $\begin{array}{l}\text { Cronbach's } \\
\text { Alpha }\end{array}$ \\
\hline Source of Information & & 0.500 & 0.833 & 0.805 \\
\hline Digital books ${ }^{\mathrm{b}}$ & - & & & \\
\hline Search Engines & 0.712 & & & \\
\hline $\begin{array}{l}\text { Multimedia production tools (e.g., PowerPoint, video editing, and digital } \\
\text { recording) }\end{array}$ & 0.676 & & & \\
\hline Broadcasting tools (e.g., publish a podcast, upload to YouTube) & 0.719 & & & \\
\hline E-mail & 0.723 & & & \\
\hline Any chatting software (e.g., MSN, Skype) & 0.704 & & & \\
\hline Digital learning games, computer/video games ${ }^{b}$ & - & & & \\
\hline Information Seeking & & 0.513 & 0.754 & 0.850 \\
\hline Information is instantly accessible. ${ }^{b}$ & - & & & \\
\hline Low-cost information is accessible (or free) ${ }^{b}$ & - & & & \\
\hline The information is current. ${ }^{b}$ & - & & & \\
\hline From my PC, I can access and download the information. & 0.536 & & & \\
\hline A recognised expert or authority has authored or supported the content. & 0.827 & & & \\
\hline To suit my information needs, the data has been packed and filtered. & 0.753 & & & \\
\hline Information Need & & 0.520 & 0.811 & 0.768 \\
\hline Always the information needs of local users are made accessible online & 0.697 & & & \\
\hline The online information on livelihoods is up to date & 0.814 & & & \\
\hline The information on the Web page about livelihoods is adequately available. & 0.704 & & & \\
\hline The information is more relevant to the livelihoods of local communities & 0.660 & & & \\
\hline Livelihoods information provided is locally useful and valuable. ${ }^{b}$ & - & & & \\
\hline Useful information on livelihoods is only available in the English language. ${ }^{b}$ & - & & & \\
\hline I trust the information that I received from ICTs is reliable and accurate ${ }^{b}$ & - & & & \\
\hline Information Sharing & & 0.573 & 0.923 & 0.80 \\
\hline In online communities, I frequently share livelihood information with others & 0.691 & & & \\
\hline I am one of the active participants and contributors in online communities & 0.773 & & & \\
\hline $\begin{array}{l}\text { I make a conscious effort to spend time being involved in activities that } \\
\text { contribute livelihood information to the online community }\end{array}$ & 0.801 & & & \\
\hline $\begin{array}{l}\text { In an online community, I try to create and share livelihoods information } \\
\text { with others }\end{array}$ & 0.787 & & & \\
\hline $\begin{array}{l}\text { In online communities, others find my information-sharing contributions to } \\
\text { be beneficial. }\end{array}$ & 0.764 & & & \\
\hline $\begin{array}{l}\text { In online communities, my contributions to the livelihood information enable } \\
\text { others to create new livelihood opportunities }\end{array}$ & 0.717 & & & \\
\hline $\begin{array}{l}\text { In the online communities, I am a knowledgeable contributor to the } \\
\text { sustainable livelihood of local communities }\end{array}$ & 0.788 & & & \\
\hline
\end{tabular}


In online communities, the information I share with others have a positive impact on their livelihoods and incomes

I feel the value of my information-sharing efforts is of larger value to the online community.

\section{Sustainable Livelihood}

Human asset ${ }^{\mathrm{b}}$

Social asset

Financial asset

Physical asset

Natural asset ${ }^{\mathrm{b}}$
0.726

0.773

0.837

${ }^{\mathrm{a}} \chi^{2}=502.181 . d . f=242\left(\chi^{2} / d . f=2.075\right), p=0.000, \mathrm{GFI}=0.872, \mathrm{IFI}=0.927, \mathrm{TLI}=0.916, \mathrm{CFI}=0.926, \mathrm{RMSEA}=0.060 .{ }^{\mathrm{b}}$ The item was deleted after confirmatory factor analysis

\subsection{Structural Paths and Hypotheses Testing}

This model includes information sources, information seeking, information need, and information sharing as exogenous variables, and sustainable livelihood as an endogenous variable. First, the structural model was tested for model fit. The results implied a good model fit $\left(\chi^{2}=502.181, \chi^{2} / \mathrm{df}=242\right.$, AGFI $=0.872, \mathrm{GFI}=0.844, \mathrm{CFI}=$ 0.909 , RMSEA $=0.060$, TLI $=0.916$ ) with two indices $($ CFI and IFI) exceeding the cut-off value of 0.90 . The RMSEA value was cut to between 0.03 and 0.08 , which is within the recommended range of adequate values (Hair et al., 2013). Since the model has displayed a good fit for the data in this study, the results of the hypothesis testing could be measured with confidence. Table 3 presents the path and parameter estimates related to the structure model. Based on the findings, the path coefficients in the model indicate that the relationship between information sources and sustainable livelihood was hypothesized as not significant at $p>0.05$ (H1). The result also showed that hypothesis $\mathrm{H} 2$ was rejected; which assumes no relationship between information seeking and sustainable livelihood. It can be seen from the data in Table 3 that two positive associations exist between information sharing and information need and sustainable livelihood among Malaysian youth. The findings of this study indicate that information sharing and information needs are valuable predictors of sustainable livelihood. These variables explained $59.0 \%$ of the variance in sustainable livelihood.

Table 3. Analysis of the structural model.

\begin{tabular}{|c|c|c|c|c|c|}
\hline Hypotheses & & Path & & Standardized Estimate & Decision \\
\hline $\mathrm{H}_{1}$ & Information sources & $\rightarrow$ & sustainable livelihood & 0.068 & Rejected \\
\hline $\mathrm{H}_{2}$ & Information Seeking & $\rightarrow$ & sustainable livelihood & 0.078 & Rejected \\
\hline $\mathrm{H}_{3}$ & Information need & $\rightarrow$ & sustainable livelihood & 0.138 & Supported \\
\hline $\mathrm{H}_{4}$ & Information Sharing & $\rightarrow$ & sustainable livelihood & 0.611 & Supported \\
\hline
\end{tabular}

\section{Discussion and Implications}

The study used ICT to study the information behavior of Malaysian youth. The study aimed to investigate the function of ICT to determine the information behavior of Malaysian youth through its implications on sustainable livelihood opportunities. Four hypotheses were examined in the study. Based on the results, three hypotheses were supported. It was found that information need had a positive and significant relationship with a sustainable livelihood. The findings were consistent with previous studies (Lwoga, 2014; Yohannis et al., 2017). Ahmed et al. (2009) noted that information needs were largely centered on the problems of daily life and the earning of livelihoods. In another study, Khan (1997) stated that young people in the United States and the United Kingdom needed information to improve their lives, which included consumer information, information on transportation, personal finances, time, and weather.

Furthermore, the relationship between information sharing and sustainable livelihood was supported in the present study. The findings demonstrated that information sharing was directly influenced by the youth's sustainable livelihood and this was consistent with previous research findings (Hertzum \& Hansen, 2019). This meant that information sharing was one of the most popular online activities for Malaysian youths and can provide an additional information channel, which may enhance their sustainable livelihood. The results also evidently displayed that the youth in this research shared information to resolve their everyday problems. It can 
be suggested that they exchanged information to solve their daily problems. The youth requested information from others and were willing to share what they know; thus, increasingly create information collectively or collaboratively. The continuous youth engagement in collaborative problem solving was facilitated by exchanging network-related comments or actions to provide livelihood information (Serrat, 2017). As Avgerou (2010) stated, many telecenter users informally shared the information they found on the Internet with friends or family members, most often about homework, entertainment, or other information needs.

Similarly, Yohannis et al. (2017) established that ICT, such as the telecenters, specified an extra shared space for communities to share information about employment and other accessible opportunities. They allowed information sharing on the main results happening in their communities. The results from previous studies revealed that people used mobile phones to support their business operations in terms of their agricultural production and livestock expansion. For instance, by accessing business information such as prices of materials and services, communicating with customers and suppliers, interacting with business support organizations, and so on (Baro \& Endouware, 2013; Makoza \& Chigona, 2012; Martin \& Abbott, 2011; Sey, 2011; Sife et al., 2010). These studies frequently referred to information flows involved in markets and participants. Another example of the transformative nature of telecenters can be seen in Tanzania, where a country dweller is capable of bargaining with a middleman to get better values and stipulate local products according to marketplace demands, which is made likely by the telecenter staff who provide market information in the local language (Malanga \& Banda, 2021).

In contrast, the findings revealed that there was no link between knowledge seeking and sustainable livelihood. While the information was essential to the Malaysian population, the youth were found to be unaware of where to seek information. The results of this study also discovered some problems encountered by youths while searching for livelihood information. These issues, according to Julien (2004), include not knowing where to get information, being overwhelmed by the options, and being unable to articulate a query. Some youths, on the other hand, lacked fundamental critical thinking and information literacy skills. Critical thinking has received a lot of attention in the literature since it is crucial to the learning process and cognitive growth, which includes searching for information. When the Educational Testing Service (ETS) examined 6,300 pupils in a literacy evaluation study, Çoklar et al. (2017) found that they lacked critical thinking abilities. The evaluation was carried out by evaluating students' capacity to identify, access, manage, integrate, produce, and convey knowledge in a high-tech environment using their key skills. Xu and Pratt (2018) argued that youths' critical thinking and cognitive skills were insufficient due to a lack of reading. Young individuals may know how to use a computer, but they may lack information literacy.

Then, the argument made was that youth, who did not use effort to find information, would find it problematic to analyze information critically or select which information to use for their livelihood purposes. While information sources were essential to the youth population, respondents were found to be unaware about maximizing the benefits of increased access to information and a wider choice of information sources that could contribute to livelihood decision-making. Therefore, Hypothesis 1 was also rejected. The independent information behaviors of Malaysian youth were inconsistent with the interaction between today's youth and the digital age information sources. In this way, the features of information behavior in the digital era match the nature of information sources. The youth prefer the dynamic, flexible, and interactive nature of information sources or technologies, which support the patterns of remixing and tinkering with continual modification and extermination (Castells, 2013). In summary, the relation between youth and information sources is reciprocal. The nature of information sources and technologies has an impact in shaping youth information behaviors. On the other hand, Malaysian youth can choose and reproduce based on their needs, and their behavior patterns that lead to the development and thriving of the resources that fulfill the needs; thus, this research offers several practical implications.

From a practical perspective, this study utilized solution modeling and innovative socio-technical design development to tackle the challenges of usability, validity, interoperability, reliability, and reliability of youth-made information under situations of uncertainty. It must also be counted as a standing practice to understand the Malaysian youth and if possible their information needs to design and develop portals, websites, information literacy training programs, online education and training, and web-based information retrieval systems that have become the needs of the youth. As youth further identify the difficulties involved in information searching, information specialists should intervene by directing youth to search for meaning from a greater understanding of the obtained information. Finally, information needs can be amended by providing relevant content in the native language and translating the English or global contents into the Malaysian language. This enables the majority of the youth to take advantage of the obtainable information online. 


\section{Conclusion}

There is no doubt that ICT plays a very important role in all features of Malaysian youth endeavors and that their online information actions have positively impacted the economic, political, and social lives of their communities. The study revealed the link between ICT and information behavior that enables Malaysian youths to explore and enhance the information of how ICT is employed by the youth as an imperative part of their daily lives. Additionally, the position of four predictor subgroups were emphasized, namely, information source, information seeking, information need, and information sharing. Based on the SEM analyses, the findings confirmed that information sharing had a positive influence on the livelihoods of Malaysian youths. The study showed that respondents have a strong need for sharing information and working together in many information activities related to their livelihood needs. These respondents were involved in information behavior more consistently when they felt a sense of community.

In addition, the study results revealed that there was a significant relationship between information needs and the sustainable livelihoods of Malaysian youth. This finding also concluded that information needs can assist youths to obtain information and knowledge on a variety of subjects that clearly affect them, such as education, well-being, healthcare, and employment. Then, the knowledge and information can be applied towards developing sustainable livelihoods. Contrary to our expectations, the results presented that there were no significant associations between two of these predictors (information seeking and information source) and the sustainable livelihoods of Malaysian youth. Overall, 59\% of the variance in the sustainable livelihoods of Malaysian youth was accounted for by the predicted variables.

The application of the findings encourages the growth of resource strategies, including ICTs, for young Malaysians to be able to engage in their capacity development towards sustainable livelihoods. This study also contributed to an existing body of literature on youth information behavior in ICT settings from a new perspective. The study results delivered a practical base for the growth of relevant library and information services for youth in modifying information behavior. Additionally, the results are a valuable resource for Malaysian policymakers and information managers by helping them to better comprehend the role and position of information behaviors in supporting the sustainable livelihoods of youths as well as further emphasizing the vital role of this context in ICT. ICTs are essential in ensuring that young people have a secure future. To assist young people in a systematic and successful way, the future studies must establish a clear understanding of ICT plans and their roles in livelihood of young people. ICT initiatives can be created to respond specifically to young poverty and the demand for a sustainable livelihood based on these suggestions. In addition, $41 \%$ of variance is not explained by this study and it can be a task for future studies to look for other possible factors that can affect sustainable livelihood.

\section{References}

Adeola, B. M. (2014). Information seeking behaviour and use of social scientists in selected universities in southwest Nigeria. IOSR Journal of Humanities and Social Science, 19(8), 67-74. https://doi.org/10.9790/0837-19826774

Adera, E. O., Waema, T. M., \& May, J. (2014). ICT pathways to poverty reduction: Empirical evidence from East and Southern Africa. IDRC. https://doi.org/10.3362/9781780448152

Agarwal, N. K. (2017). Exploring context in information behavior: Seeker, situation, surroundings, and shared identities. Synthesis Lectures on Information Concepts, Retrieval, and Services, 9(7), 1-163. https://doi.org/10.2200/S00807ED1V01Y201710ICR061

Ahmad, A. R., Yusoff, W. F. W., Noor, H. M., \& Ramin, A. K. (2012). Preliminary study of rural entrepreneurship development program in Malaysia. Journal of Global Entrepreneurship, 2(1), 1-8.

Ahmed, N., Lecouffe, C., Allison, E. H., \& Muir, J. F. (2009). The sustainable livelihoods approach to the development of freshwater prawn marketing systems in southwest Bangladesh. Aquaculture Economics \& Management, 13(3), 246-269. https://doi.org/10.1080/13657300903156092

Avgerou, C. (2010). Discourses on ICT and development. Information Technologies \& International Development, 6(3), 1-18.

Azimi, H., \& Zanariah, M. N. (2007). Youth Readiness as Pillar of Developed Nation [Research Report]. Centre for Extension, Entrepreneurship and Profesional Development, Universiti Putra Malaysia.

Baro, E. E., \& Endouware, B. C. (2013). The effects of mobile phone on the socio-economic life of the rural dwellers in the Niger Delta region of Nigeria. Information Technology for Development, 19(3), 249-263. 
https://doi.org/10.1080/02681102.2012.755895

Bashir, M. S., Samah, B. A., Emby, Z., Badsar, M., Shaffril, H. M., \& Aliyu, A. (2011). Information and Communication Technology Development in Malaysia: Influence of competency of leaders, location, infrastructures and quality of services on telecentre success in rural communities of Malaysia. Australian Journal of Basic and Applied Sciences, 5(9), 1718-1728.

Blake, A., \& Garzon, M. Q. (2012). Boundary Objects to Guide Sustainable Technology-Supported Participatory Development for Poverty Alleviation in the Context of Digital Divides. The Electronic Journal of Information Systems in Developing Countries, https://doi.org/10.1002/j.1681-4835.2012.tb00358.x

Brown, A. E., \& Grant, G. G. (2010). Highlighting the duality of the ICT and development research agenda. Information Technology for Development, 16(2), 96-111. https://doi.org/10.1080/02681101003687793

Brown, M. G., Wohn, D. Y., \& Ellison, N. (2016). Without a map: College access and the online practices of youth from low-income communities. Computers \& Education, 92, 104-116. https://doi.org/10.1016/j.compedu.2015.10.001

Castells, M. (2013). Communication power. OUP Oxford. https://doi.org/10.4000/books.editionsmsh.10551

Cerdan, J., Catalan-Matamoros, D., \& Berg, S. W. (2017). Online communication in a rehabilitation setting: Experiences of patients with chronic conditions using a web portal in Denmark. Patient Education and Counseling, 100(12), 2283-2289. https://doi.org/10.1016/j.pec.2017.06.023

Chiu, C.-M., Wang, E. T., Shih, F.-J., \& Fan, Y.-W. (2011). Understanding knowledge sharing in virtual communities: An integration of expectancy disconfirmation and justice theories. Online Information Review, 35(1), 134-153. https://doi.org/10.1108/14684521111113623

Çoklar, A. N., Yaman, N. D., \& Yurdakul, I. K. (2017). Information literacy and digital nativity as determinants of online information search strategies. Computers in Human Behavior, 70, 1-9. https://doi.org/10.1016/j.chb.2016.12.050

Dahalan, D., Abdullah, H., D’Silva, J. L., Ismail, I. A., \& Ahmad, N. (2013). Dependency and readiness of urban youth to utilize public transportations as their premier mode of transport. Asian Social Science, 9(1), 257-261. https://doi.org/10.5539/ass.v9n1p257

Duncombe, R. A. (2014). Understanding the impact of mobile phones on livelihoods in developing countries. Development Policy Review, 32(5), 567-588. https://doi.org/10.1111/dpr.12073

Fisher, K. E., \& Julien, H. (2009). Information behavior. Annual Review of Information Science and Technology, 43(1), 1-73. https://doi.org/10.1002/aris.2009.1440430114

Gigler, B.-S. (2014). Informational Capabilities: The missing link for understanding the impact of ICT on development. World Bank. https://doi.org/10.1596/978-1-4648-0191-4_ch2

Hair, J. F., Black, W. C., Babin, B. J., Anderson, R. E., \& Tatham, R. L. (2013). Multivariate data analysis (Vol. 6) (7th ed.). Pearson Prentice Hall.

Hassan, N. R. (2011). Is information systems a discipline? Foucauldian and Toulminian insights. European Journal of Information Systems, 20(4), 456-476. https://doi.org/10.1057/ejis.2011.2

Hertzum, M., \& Hansen, P. (2019). Empirical studies of collaborative information seeking: A review of methodological issues. J. of Documentation, 75(1), 140-163. https://doi.org/10.1108/JD-05-2018-0072

Ho, R. (2006). Handbook of univariate and multivariate data analysis and interpretation with SPSS. Chapman and Hall/CRC. https://doi.org/10.1201/9781420011111

Ito, M., Horst, H. A., Bittanti, M., Stephenson, B. H., Lange, P. G., Pascoe, C. J., ... Mahendran, D. (2009). Living and learning with new media: Summary of findings from the Digital Youth Project. MIT Press. https://doi.org/10.7551/mitpress/8519.001.0001

Jayasundara, C. C. (2021). Sexual health information seeking behaviour of adolescents and their satisfaction with the information outcome: An application of the theory of motivated information management. The Journal of Academic Librarianship, 47(5), 102383. https://doi.org/10.1016/j.acalib.2021.102383

Johnson, J. D., \& Case, D. O. (2012). Health Information Seeking (Health Communication). Peter Lang Publishing Inc.

Julien, H. (2004). Adolescent decision-making for careers: An exploration of information behavior. In M. K. 
Chelton \& C. Cool (Eds.), Youth Information-Seeking Behavior: Theories, Models, and Issues (pp. 321-352). The Scarecrow Press.

Kassim, M., \& Katunzi-Mollel, K. R. U. (2017). Seeking health information in rural context: Exploring sources of maternal health information in rural Tanzania. University of Dar Es Salaam Library Journal, 12(2), $37-61$.

Khan, B. H. (1997). Web-based instruction. Educational Technology.

Kim, S. (2018). Managing millennials' personal use of technology at work. Business Horizons, 61(2), 261-270. https://doi.org/10.1016/j.bushor.2017.11.007

Kirschner, P. A., \& De Bruyckere, P. (2017). The myths of the digital native and the multitasker. Teaching and Teacher Education, 67, 135-142. https://doi.org/10.1016/j.tate.2017.06.001

Kivunike, F. N., Ekenberg, L., Danielson, M., \& Tusubira, F. F. (2013). Developing criteria for the evaluation of the ICT contribution to social and economic development. Sixth Annual SIG GlobDev Pre-ICIS Workshop, 24.

Kline, R. B. (2016). Principles and practice of structural equation modeling (4th ed.). Guilford publications.

Lee, K. M. (2012). Influence of Mentoring on Learning Outcomes of Pioneering School-based'international Award for Young People'Programme in Malaysia [PhD Thesis]. Universiti Putra Malaysia.

Lwoga, E. (2014). Critical success factors for adoption of web-based learning management systems in Tanzania. International Journal of Education and Development Using ICT, 10(1), 4-21.

Makoza, F., \& Chigona, W. (2012). The outcomes of ICT diffusion and human development in Malawi. International Journal of Information Communication Technologies and Human Development (IJICTHD), 4(4), 52-70. https://doi.org/10.4018/jicthd.2012100105

Malanga, D. F., \& Banda, M. J. (2021). The use of mobile phones by women microenterprises in Malawi: A sustainable livelihoods perspective. Global Knowledge, Memory and Communication, ahead-of-print (ahead-of-print). https://doi.org/10.1108/GKMC-09-2020-0143

Martin, B. L., \& Abbott, E. (2011). Mobile phones and rural livelihoods: Diffusion, uses, and perceived impacts among farmers in rural Uganda. Information Technologies \& International Development, 7(4), 17-34.

Mbuyisa, B., \& Leonard, A. (2017). The role of ICT use in SMEs towards poverty reduction: A systematic literature review. Journal of International Development, 29(2), 159-197. https://doi.org/10.1002/jid.3258

Ming, L. L., Azhar, N. A., Hazri, H., \& Mulakala, A. (2012). The Youth Factor: 2012 Survey of Malaysian Youth Opinion. The Asia Foundation. https://asiafoundation.org/resources/pdfs/2012NationalYouthSurvey.pdf

Murgatroyd, P. W. (2011). Information Seeking and Information Sharing Behaviour in the Climate Change Community of Practice in the Pacific: Implications for Models of Library Services in Scientific and Technical Libraries [Master Thesis]. Victoria University of Wellington.

MYI. (2011). Malaysian Institute for Research in Youth Development. Retrieved from http://www.ippbm.gov.my/v3-en/index.php/publications.html?id=253.

Omar, S. Z., Shaffril, H. A. M., Bolong, J., \& D’Silva, J. L. (2012). Investigating rural library usage among rural youth in Malaysia: Its corresponding determinants and impacts. Computer and Information Science, 5(2), 98-104. https://doi.org/10.5539/cis.v5n2p98

Park, J., Konana, P., Gu, B., Leung, A. C. M., \& Chung, A. (2010). An Investigation of Information Sharing and seeking Behaviors in Virtual Communities. ICIS, 242.

Petrosillo, I., Costanza, R., Aretano, R., Zaccarelli, N., \& Zurlini, G. (2013). The use of subjective indicators to assess how natural and social capital support residents' quality of life in a small volcanic island. Ecological Indicators, 24, 609-620. https://doi.org/10.1016/j.ecolind.2012.08.021

Sæbø, Ø., \& Thapa, D. (2012). Introducing internet-based services in the mountain areas of Nepal: An asset Pentagon perspective. Information Technologies \& International Development, 8(3), 85-98.

Sarka, P., \& Ipsen, C. (2017). Knowledge sharing via social media in software development: A systematic literature review. Knowledge Management Research \& Practice, 15(4), 594-609. https://doi.org/10.1057/s41275-017-0075-5

Saunders, C., Wiener, M., Klett, S., \& Sprenger, S. (2017). The impact of mental representations on ICT-related 
overload in the use of mobile phones. Journal of Management Information Systems, 34(3), 803-825. https://doi.org/10.1080/07421222.2017.1373010

Serrat, O. (2017). The sustainable livelihoods approach. In Knowledge solutions (pp. 21-26). Springer. https://doi.org/10.1007/978-981-10-0983-9_5

Sey, A. (2011). 'We use it different, different': Making sense of trends in mobile phone use in Ghana. New Media \& Society, 13(3), 375-390. https://doi.org/10.1177/1461444810393907

Shi, D., Lee, T., \& Maydeu-Olivares, A. (2019). Understanding the model size effect on SEM fit indices. Educational and Psychological Measurement, 79(2), 310-334. https://doi.org/10.1177/0013164418783530

Sife, A. S., Kiondo, E., \& Lyimo-Macha, J. G. (2010). Contribution of mobile phones to rural livelihoods and poverty reduction in Morogoro region, Tanzania. The Electronic Journal of Information Systems in Developing Countries, 42(1), 1-15. https://doi.org/10.1002/j.1681-4835.2010.tb00299.x

Silva, S., Badasyan, N., \& Busby, M. (2018). Diversity and digital divide: Using the National Broadband Map to identify the non-adopters of broadband. Telecommunications Policy, 42(5), 361-373. https://doi.org/10.1016/j.telpol.2018.02.008

Sobeih, A. (2007). ICT and enterprise development (pp. 21-22). Sustainable Development Association. Retrieved from http://www.yesweb.org/yes2008/doc/ICT\%26Enterprise_Development.pdf

Soh, M. C., \& Omar, S. K. (2017). Journey of indigenous knowledge for sustainable livelihood: Story from East Coast, Malaysia. Journal of Asian Behavioural Studies, 2(5), 27-36. https://doi.org/10.21834/jabs.v2i5.216

Williamson, K., \& Roberts, J. (2010). Developing and sustaining a sense of place: The role of social information. Library \& Information Science Research, 32(4), 281-287. https://doi.org/10.1016/j.lisr.2010.07.012

$\mathrm{Xu}, \mathrm{X}$., \& Pratt, S. (2018). Social media influencers as endorsers to promote travel destinations: An application of self-congruence theory to the Chinese Generation Y. Journal of Travel \& Tourism Marketing, 35(7), 958-972. https://doi.org/10.1080/10548408.2018.1468851

Yang, C., Nay, S., \& Hoyle, R. H. (2010). Three approaches to using lengthy ordinal scales in structural equation models: Parceling, latent scoring, and shortening scales. Applied Psychological Measurement, 34(2), 122-142. https://doi.org/10.1177/0146621609338592

Yassin, S. M., Hamzah, A., Samah, B. A., Samah, A. A., Idris, K., Kamarudin, N., \& Shaffril, H. A. M. (2014). Rural Youth Sustainable Livelihood: Some Preliminary Results. The Social Sciences, 9(4), 261-264.

Yohannis, M. A., Waema, T. M., \& Hutchinson, M. (2017). Linking climate information to livelihood strategies through ICTs: The role of integrated sustainable livelihoods framework. 2017 IST-Africa Week Conference (IST-Africa), 1-8. https://doi.org/10.23919/ISTAFRICA.2017.8102295

Yusop, F. D., \& Sumari, M. (2013). The use of social media technologies among Malaysian youth. Procedia-Social and Behavioral Sciences, 103, 1204-1209. https://doi.org/10.1016/j.sbspro.2013.10.448

Zaremohzzabieh, Z., Samah, B. A., Omar, S. Z., Bolong, J., \& Shaffril, H. A. M. (2014). Youths' Sustainable Livelihood with Information and Communication Technologies: Toward an ICT for Development Quality Model. American Journal of Applied Sciences, 11(6), 947-958. https://doi.org/10.3844/ajassp.2014.947.958

Zhan, L., Sun, Y., Wang, N., \& Zhang, X. (2016). Understanding the influence of social media on people's life satisfaction through two competing explanatory mechanisms. Aslib Journal of Information Management, 68(3), 347-361. https://doi.org/10.1108/AJIM-12-2015-0195

\section{Copyrights}

Copyright for this article is retained by the author(s), with first publication rights granted to the journal.

This is an open-access article distributed under the terms and conditions of the Creative Commons Attribution license (http://creativecommons.org/licenses/by/4.0/). 